\section{Separation of the genetic loci for the $H-Y$ antigen and for testis determination on human $Y$ chromosome}

\author{
Elizabeth Simpson*, Phillip Chandler*, Els Goulmy ${ }^{\dagger}$, \\ Christine M. Disteche ${ }^{\ddagger}$, Malcolm A. Ferguson-Smith ${ }^{\S}$ \\ \& David C. Pagell
}

* Transplantation Biology Section, Clinical Research Centre, Harrow, Middlesex HA1 3UJ, UK

$\dagger$ Department of Immunohaematology and Blood Bank AZL, University Hospital Leiden, The Netherlands

$\ddagger$ Department of Pathology, University of Washington, Seattle, Washington 98195, USA

§ Duncan Guthre Institute of Medical Genetics,

University of Glasgow, Glasgow, G3 8SJ, UK

|| Whitehead Institute, Cambridge Massachusetts 02142, USA

The mammalian Y chromosome encodes a testis-determining factor (termed TDF in the human), a master regulator of sex differentiation. Embryos with a $Y$ chromosome develop testes and become males whereas embryos lacking a $Y$ chromosome develop ovaries and become females. Expression of $\mathrm{H}-\mathrm{Y}$, a minor histocompatibility antigen, may also be controlled by a gene on the $Y$ chromosome, and it has been proposed that this antigen is the testis-determining factor $^{1}$. We have tested the postulated identity of $H-Y$ and TDF in the human. $H-Y$ typing with $T$ cells was carried out on a series of seX-reversed humans (XX males and XY females), each shown by DNA hybridization to carry part but not all of the $Y$ chromosome. This deletion analysis maps the gene for $\mathrm{H}-\mathrm{Y}$ to the long arm or centromeric region of the human $Y$ chromosome, far from the TDF locus, which maps to the distal short arm.

$\mathrm{H}$-Y typing of sex-reversed mice has shed light on the relationship of this antigen to gonadal sex determination XX Sxr (sex reversed) mice are both male and $H-Y$ positive owing to the presence of a small portion of the $Y$ chromosome ${ }^{23}$, consistent with a testis-determining role for $\mathrm{H}-\mathrm{Y}$ However, a derivative of $S x r$ known as $S x r^{\prime}$ produces XX $S x r^{\prime}$ and XO $S x r^{\prime}$ mice that are phenotypically male but $\mathrm{H}-\mathrm{Y}$ negative ${ }^{45}$, demonstratıng that the antigen is not required for testis determination

In humans, DNA hybridization studies using Y-specific probes of individuals with only parts of the normal $Y$ chromosome have yielded an eight-interval deletion map of the $Y$ chromosome Such studies of XX males and XY females that carry part but not all of the $\mathrm{Y}$ chromosome, have demonstrated that interval 1, representing a portion of the distal short arm of the $\mathrm{Y}$, contains $T D F^{67}$ Similar studies of another series of $\mathrm{XX}$ males, using a different set of Y-DNA probes, likewise show them to possess sequences both within and distal to Yp11 2 (refs 8 and 9) We reasoned that if there is a Y-chromosomal gene responsible for $\mathrm{H}-\mathrm{Y}$ antigen expression then it should be possible to map that gene by $\mathrm{H}-\mathrm{Y}$ typing individuals with wellcharacterized $Y$ deletions

H-Y-specific T-cell clones and lines have been derived in vitro from transfused human female aplastıc anaemia patients ${ }^{10}$ These $\mathrm{H}-\mathrm{Y}$ spectic $\mathrm{T}$ cells, whose response is HLA restricted, were used to $\mathrm{H}-\mathrm{Y}$ type Epstein-Barr-Virus-transformed B-cell lines from deleted-Y individuals Because only HLA-A2 or B7-restricted $\mathrm{H}$-Y-specific $\mathrm{T}$-cell clones were avallable at the tıme of this study, we were able to H-Y type only those deleted-Y individuals who were HLA-A2 and/or -B7 Variants of HLA-A2 and $-B 7$ which cannot be recognized by allogeneic or HLArestricted $T$ cells have been described ${ }^{11}$ Accordingly, in each case, the HLA type was determined serologically and confirmed using alloreactive cytotoxic $T$ cells

Table 1 shows the results of HLA and H-Y typing of eight deleted- $Y$ individuals ( $\mathrm{S} 1 \mathrm{X} 46, \mathrm{XX}$ males and two 46, XY females) All six $X X$ males were negative for $\mathrm{H}-\mathrm{Y}$ These include three XX males, LGL105, WHT950 and WB, who carry intervals 1 ,
2 and 3 of the $Y$ chromosomal short arm (refs 6 and 12, D C P unpublished results, see class 3 XX males in F1g 1) and three XX males, RH, JT and JM, with similar portions of the Y short arm detected using a different set of Y-DNA probes ${ }^{89}$ Whereas $T D F$ is in interval 1 of the $Y$ chromosome ${ }^{67}$, these results indicate that the gene for $\mathrm{H}-\mathrm{Y}$ lies outside intervals 1,2 and 3

This conclusion is reinforced by the finding that both $X Y$ females are positive for H-Y XY female WHT1003 has a deletion of intervals 1,2 and 3 on the $Y$ short arm, whereas $X Y$ female WHT715 has a deletion of intervals 1,2 and 4A (refs 7 and 13, see class 1 and $2 X Y$ females in Fig 1) Taken together, these results with $X X$ males and $X Y$ females strongly suggest that the gene for $\mathrm{H}-\mathrm{Y}$ maps somewhere in intervals $4 \mathrm{~B}$ to 7 of the $\mathrm{Y}$ chromosome, that is, near the centromere or on the long arm (refs 6 and 7, Fig 1)

The finding that $\mathrm{XX} S x r^{\prime}$ male mice were $\mathrm{H}-\mathrm{Y}$ negative strongly suggested that $\mathrm{H}-\mathrm{Y}$ is not the testis determinant However, it might be that the $S x r^{\prime}$ mutation had affected the antigenicity but not the testis-determining capability of $\mathrm{H}-\mathrm{Y}$ There is an earlier report of human $X X$ males with negative $\mathrm{H}-\mathrm{Y}$ type and an $\mathrm{XY}$ female with positive $\mathrm{H}-\mathrm{Y}$ type with cytotoxic $T$ cells ${ }^{14}$ However, the $X X$ males had not been tested for the presence of Y-chromosomal DNA and the XY female had not been tested for deletions of Y DNA sequences The results reported here are not subject to such ambiguities of interpretation In the present study, H-Y typing was carried out on cells from eight sex-reversed individuals with well-characterized deletions of portions of the $Y$ chromosome The combination of negative and positive findings reported here demonstrates unequivocally that the gene for H-Y maps far from interval 1, which contains TDF and that $\mathrm{H}-\mathrm{Y}$ antigen is not the testisdetermining factor $\mathrm{H}-\mathrm{Y}$ antigen was originally defined by graft rejection $^{15}$ The $i n$ vitro T-cell assays of the type used for $\mathrm{H}-\mathrm{Y}$ typing in this study have been shown to recognize the same histocompatibility antigen as that defined by graft rejection ${ }^{16}$ In contrast, serological identification of a male antigen assumed to be $\mathrm{H}-\mathrm{Y}$ (and now called serologically detected male antigen, SDM) has been problematical In particular, there is doubt concerning whether the SDM antigen is identical to the $\mathrm{H}-\mathrm{Y}$ histocompatibility antigen ${ }^{517}$ The implications of the present study, therefore, are limited to the $\mathrm{H}-\mathrm{Y}$ antigen and do not extend to the SDM antigen

We are currently examınıng additional deleted-Y individuals in an effort to map the H-Y locus more precisely The possibility that the $\mathrm{H}-Y$ gene might be identical to or near a spermatogenesis factor on the long arm of the human $Y$ chromosome ${ }^{18}$ is of particular interest, because in mice $\mathrm{H}-\mathrm{Y}$ (or a closely linked gene) has been implicated in spermatogenesis ${ }^{19}$ Though the results reported here imply that $\mathrm{H}-\mathrm{Y}$ has no function in gonadal sex determination, it may be involved in testis function at a later stage of development

We thank Els Blokland and Jos Pool for isolating $\mathrm{H}-\mathrm{Y}$ specific T-cell lines and clones and for assistance with the typing, Albert de la Chapelle, Joseph Hersh and Martin Crawfurd for providing cell lines and blood samples, and Lesley Snadden for help in settıng up and maintaining EB transformed lymphoblastold lines This work was supported in part by grants from the MRC

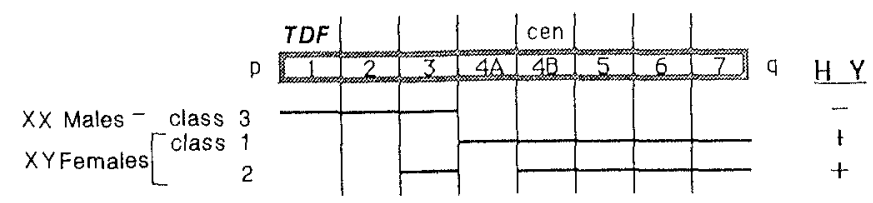

Fig 1 Eight interval deletion map of the human Y chromosome (based on refs 7 and 13) The results of $\mathrm{H}-\mathrm{Y}$ typing of individuals (from Table 1) are summarized The short arm, centromere and long arm of the $\mathrm{Y}$ chromosome are denoted by, respectively ' $\mathrm{p}$, cen' and 'q TDF gene for testis determining factor Horizontal lines, portions of the chromosome present in the designated individual 
Table 1 HLA and H-Y typing of B-cell lines from XX males, XY females and normal controls

\begin{tabular}{|c|c|c|c|c|c|c|}
\hline \multirow[b]{2}{*}{ Experiment } & \multirow[b]{2}{*}{ Karyotype/sex } & \multirow[b]{2}{*}{ Individual } & \multirow[b]{2}{*}{ HLA serology* } & \multicolumn{2}{|c|}{ Specific lysis (\%) } & \multirow{2}{*}{$\mathrm{H}-\mathrm{Y}$ phenotype } \\
\hline & & & & $\alpha \mathbf{A}-2$ & $\alpha \mathrm{H}-\mathrm{Y} / \mathrm{A}-2$ & \\
\hline \multirow[t]{5}{*}{1} & $\mathrm{XX} \delta$ & RH & $\mathrm{A} 2$ & $\underline{18}$ & 9 & - \\
\hline & $X X \sigma^{*}$ & JT & A2 & $\underline{24}$ & 3 & - \\
\hline & $\mathrm{XX}$ & LGL 105 & $\mathrm{~A} 2$ & $\underline{13}$ & 4 & - \\
\hline & $X Y ð$ & Normal male & $\mathrm{A} 2$ & 20 & $\underline{38}$ & + \\
\hline & $\mathrm{XX}$ ? & Normal female & $\mathrm{A} 2$ & $\underline{17}$ & 8 & - \\
\hline \multirow[t]{4}{*}{2} & $\mathrm{XXO}$ & WB & A2 & 37 & 0 & - \\
\hline & $X Y O$ & Normal male & $\mathrm{A} 2$ & $\underline{25}$ & $\underline{17}$ & + \\
\hline & $\mathrm{XX} 9$ & Normal female & $\mathrm{A} 2$ & 17 & 3 & - \\
\hline & & & & $\alpha B 7$ & $\alpha \mathrm{H}-\mathrm{Y} / \mathrm{B} 7$ & \\
\hline \multirow[t]{4}{*}{3} & $\mathrm{XX} \sigma$ & WHT950 & B7 & $\underline{76}$ & 9 & - \\
\hline & $\mathrm{XXO}$ & $\mathbf{J M}$ & B7 & $\underline{62}$ & 1 & - \\
\hline & XYठ & Normal male & B7 & $\overline{N D}$ & $\underline{40}$ & + \\
\hline & $\mathrm{XX}$ 우 & Normal female & B7 & $\underline{54}$ & 0 & - \\
\hline \multirow[t]{4}{*}{4} & $\mathrm{XY}$ ? & WHT 1003 (case 1) & B7 & 55 & $\underline{70}$ & + \\
\hline & $\mathrm{XY}$ 우 & WHT 715 (case 2) & B7 & $\underline{57}$ & 69 & + \\
\hline & XYठ & Father of case 2 & B7 & $\underline{52}$ & 61 & + \\
\hline & $\mathrm{XX}$ ? & Mother of case 2 & B7 & $\underline{36}$ & $\overline{6}$ & - \\
\hline
\end{tabular}

The H-Y-specific cytotoxic $\mathrm{T}$ cells were T-cell lines or clones derived from the peripheral blood of transfused female aplastic anaemia patients ${ }^{10}$ The alloreactive cytotoxic $T$ cells were derived from the peripheral blood of healthy individuals ${ }^{11}$. They were used in the cytotoxic assays $5-7$ days after aliquots previously stored in liquid nitrogen had been thawed and restimulated in vitro with appropriate antigen bearing irradiated peripheral blood cells in the presence of interleukin-2 (IL-2) in RPMI medium containing penicillin, streptomycin, glutamine, HEPES and $10 \%$ fetal calf serum (FCS) or human serum. The target cells were Epstein-Barr virus (EBV)-transformed B-cell lines grown in vitro. Immediately before the assay, aliquots were labelled with ${ }^{51} \mathrm{Cr}$-labelled sodium chromate, washed and dispensed at $5 \times 10^{3}$ cells per well in round-bottomed microtitre wells. Triplicate wells were used at each A: $\mathrm{T}$ ratio ${ }^{3,4,14}$. Per cent specific lysis given is that at an attacker-to-target ratio of $10: 1$, the figure being taken from a regression analysis of a three or four point titration curve. Underlined figures are positive values on titration curves whose $r^{2}$ value lay between 0.70 and 1.00 (refs 3,4 and 14). ND, Not done.

* HLA serology of the B-cell lines from sex-reversed patients and the parents of one was performed either by Lorna Kennedy at the ICRF Lincoln's Inn Field, or by Donald Palmer in the Department of Immunology, Hammersmith Hospital. Normal male and female cells in experiments 1-3 were EBV-transformed B-cell lines from Professor A. Rickinson of Birmingham: the individuals from which they had been obtained were serologically identified as $\mathrm{A} 2$ or B7 by him.

(MAFS), the NIH, the March of Dimes, the American Cancer Society, the Dutch Foundation for Medical Health Research (Medigon), which is subsidized by the Dutch Organisation for the Advancement of Pure Research (ZWO) and the J. A. Cohen Institute for Radiophathology and Radiation Protection (IRS).

Received 3 February, accepted S March 1987

Wachtel, S S, Ohno, S, Koo, G C \& Boyse, E A Nature 257, 235-236 (1975)

Bennett, D et al Nature 265, 255-257 (1977)

Simpson, E , Edwards, P, Wachtel, S S, McLaren, A \& Chandler, P Immunogenetics 13, $355-358$ (1981)

4 McLaren, A, Simpson, E, Tomonan, K, Chandler, P \& Hogg, H Nature 312, 552-555 (1984)
5 Stmpson, E Cell 44, 813 814 (1986)

6 Vergnaud, $G$ et al Am. $J$ hum Genet 38, 109-124 (1986)

7 Page, D C. Cold Spring Harb Symp quant Bol 51, 229-235 (1986)

8 Affara, $\mathrm{N}$ A et al Nucletc Actds Res 14, 5353-5373 (1986)

9 Affara, N A et al Nucleic Acids Res 14, 5375-5387 (1986)

10 Goulmy, E Progress in Allergy 36, 44-72 (1985)

11 Hora1, S, van der Poel, J J \& Goulmy, E Immunogenettcs 16, 135-142 (1982)

2 Andersson, M, Page, D C \& de la Chapelle, A Sceence 233, 786-788 (1986)

13 Disteche, C M et al Proc natn Acad Scl US A 83, 7841-7844 (1986)

14 Goulmy, E, van Leeuwen, A , Blokland, E, Sachs, E S \& Geraedts, J P M Immunogenetucs $17,523-531(1983)$

15 Etchwald, E J \& Sitmser, C R Transplant Bull. 2, 148 (1955)

16 Simpson, E et al Immunology 57, 345-349 (1986)

16 Simpson, E et al Immunology $57,345-349$ (1986)

17 Silvers, W K, Gasser, D L \& Eicher, E M Cell 28, 439-440

19 Burgoyne, P S , Levy, E R \& McLaren, A Nature 320, 170- 172 (1986) 